\section{Recent Earthquakes Recorded in the British Isles}

The earthquake widely noted in Britain on December 30, 1944, was recorded at Kew. From a prelim. inary reading of the record, it appears to have registered first at $00 \mathrm{~h} .36 \mathrm{~m}$. 14s. G.M.T. from an epicentral distance of $300 \mathrm{~km}$. This would make the initial time of the shock $00 \mathrm{~h} .35 \mathrm{~m}$. 35s. G.M.T. Four strong shocks were recorded at Kew between January 9 and February 13, 1945. The strongest was on February 10, when an earthquake beginning in the region of Japan attained a ground amplitude of $145 \mu$ at Kew. Mr. E. W. Pollard recorded two strong shocks on January 12 and 18, and earthquakes or tremors on February 10, 13, 17, 18 and 26 at his observatory at Binstead, Isle of Wight. The United States Coast and Geodetic Survey determined the epicentre of the earthquake of January 1, 1945, to have been near Baffin Bay.

\section{War and Infectious Diseases}

AT a Chadwick Lecture on this subject delivered on February 20 at the Royal Society of Tropical Medicine and Hygiene, Dr. J. D. Rolleston discussed the various acute infectious diseases in relation to war in the following alphabetical order: cerebrospinal fever, diphtheria, dysentery, enteric fever, infectious hepatitis, malaria, measles, mumps, scarlet fever, small-pox, streptococcal infections, typhus fever and war wounds. Chronic infections, particularly tuberculosis and syphilis, were not considered. Comparative novelties mentioned in the lecture included diphtheria of the skin, infective hepatitis, the striking decline in the incidence and mortality of enteric fever, and the introduction of new specific remedies, of which the most valuable were penicillin for war wounds, sulphaguanidine for dysentery and atebrin for malaria.

\section{Poliomyelitis Epidemic in America}

According to Mr. B. O. Connon, president of the National Foundation for Infantile Paralysis ( $J$. Roy. Inst. Pub. Health and Hyg., Feb.), the 1944 opidemic in the United States has been the second worst in the recorded history of the disease. The seven States most severely menaced are New York, North Carolina, Pennsylvania, New Jersey, Virginia, Ohio and Kentucky. The peak of the epidemic was reached in the week ending September 2, when 1,683 cases were reported.

\section{Colonial Office Appointments}

THe following appointments have recently been made in the Colonial Services: D. P. Pielou, to be entomologist, Northern Rhodesia ; E. G. A. Benson, agricultural superintendent, British Guiana, to be agricultural officer, Trinidad; J. D. Brown, senior agricultural officer, Nigeria, to be principal agricultural officer, Nigeria; M. A. G. Hanschell, agricultural superintendent, British Guiana, to be agricultural officer, Sierra Leone ; L. P. Henderson, agricultural officer, Nigeria, to be senior agricultural officer, Nigeria ; A. Pitcairn, assistant director of agriculture, Cyprus, to be senior agricultural officer (supernumerary), Tanganyika; F. E. V. Smith, principal assistant secretary (Development Branch), Nigeria, to be development secretary, Nigeria; C. B. Taylor, agricultural officer, Nigeria, to be senior agricultural officer, Nigeria; D. H. Urquhart, assistant director of agriculture, Nigeria, to be director of agriculture, Gold Coast; R. G. M. Willan, assistant conservator of forests, Cyprus, to be assistant conservator of forests, Nyasaland; E. D. Fort, surveyor, Gold Coast, to be senior surveyor, Gold Coast.

\section{Prizes for Scientific Instrument Manufacture}

Mr. W. Bowen, governing director of the Bowen Instrument Co., Ltd., Cables and Plastics, Ltd., and Bowen Research, has presented to the Scientific Instrument Manufacturers' Association a substantial capital sum, the income of which he wishes to be devoted towards the encouragement and development of invention, design, research, processes and manufacturing technique in the scientific instrument manufacturing industry. The Council of the Association has accordingly drawn up a deed of trust under which the income from the fund is to be devoted each year to prizes to be awarded to the employees of members submitting papers fulfilling the objects of the trust. For the current year the Council has decided to award five prizes to the value of $£ 25$ each for $(a)$ a new invention; (b) an improvement of design; (c) an improvement in manufacturing technique; (d) a new development or new process arising from research; and a list of topics defining the subjects or instruments admissible has been drawn up. Candidates should furnish a short description of one of the above subjects not exceeding 3,000 words with relevant sketches or diagrams, and they must be employees of members of the Association. All papers must be submitted to the secretaries of the Association, Messrs. Binder, Hamlyn and Co., River Plate House, 12-13 South Place, London, E.C.2, not later than December 31, 1945.

\section{Announcements}

Dr. N. Feather, lecturer in physics in the University of Cambridge, has been appointed professor of natural philosophy in the University of Edinburgh, in succession to the late Prof. C. G. Barkla.

Dr. L. C. BurRILI has been appointed professor of naval architecture at King's College, Newcastleupon-Tyne, as from October 1, 1945. Dr. Burrill is thirty-nine years of age. He has had a wide practical experience of naval architecture with Messrs. Swan Hunter and Wigham Richardson, Ltd. (192934), and the Manganese Bronze and Brass Co., Ltd., where he has held the position of naval architect since 1936. In addition to extensive research resulting in the recent award of the degrees of M.Sc. and Ph.D. in naval architecture, he also lectured at the Rutherford Technical College, Newcastle-upon-Tyne, for three years.

Messrs. Power Jets (Research and Development), Ltd., Whetstone, Leicester, have formed a Trade Catalogue Section in their Whetstone Library. Firms interested and associated in the production of machine tools, factory plant and equipment, physical and chemical laboratory equipment, electrical equipment, switch gear, motors, transformers, generators, etc., hydraulic pumps, air compressors, etc., who are willing to deposit a copy of their latest catalogues with Messrs. Power Jets (Research and Development), Ltd., are asked to send copies of their publications to the Librarian, Power Jets (Research and Development), Ltd., Whetstone, Leicester, for inclusion in the Library. 